\title{
STRESS DISTRIBUTION \\ INVESTIGATION \\ AT THE TAPERED SANDWICH ENDINGS
}

\author{
FRANTIŠEK LÖFFELMANN \\ Institute of Aerospace Engineering, Faculty of Mechanical Engineering, Brno University of Technology, \\ Technická 2896/2, 61669 Brno, Czech Republic \\ Frantisek.Loffelmann@vutbr.cz
}

\begin{abstract}
One of the typical sandwich ending is tapered transition to a solid laminate, which causes significant stress distribution changes. The reviewed articles show that tapered area causes increase in the shear stress in the core, increase of the axial forces in the facesheets and local bending at the fork point, at points of the tapering angle change, and at ply drop positions. Most of the studies gave attention to the endings without reinforcing. During Erasmus + internship at KTH 2D model of the tapered ending with reinforcing plies, various geometry and resin filler in the core tip was investigated to see the influence on the stress distribution. It was found that tension load case is not as critical as bending load case. Increasing of the solid laminate thickness, adding plies and inserting a short resin or adhesive filler into the core tip area lead to significant stress reduction, whereas in the transition point, from tapering to constant thickness sandwich, increasing radius is more efficient than reinforcing plies in regard to reduce stress concentration.
\end{abstract}

Keywords: Sandwich endings, Tapering, Ramp, Closeout, FEM, Filler, Ply drop.

\section{INTRODUCTION}

Sandwich structures are widely used on secondary structures of large aircrafts and in case of light composite aircrafts also for primary structures providing high bending stiffness. One of the commonly used sandwich ending consists of the tapered transition of the sandwich to the solid laminate closing the sandwich and enabling its connection to an adjacent part. Presented study is focused on this kind of endings and tries to wider understanding from the structural point of view by finite element simulations with variation of several design parameters of geometry variation, added plies and adhesive filler. Review of literature is written relatively widely including experimental studies, analytical findings, and investigation of sandwiches with functionally graded core. 


\subsection{Review of literature}

From experimental studies Kuczma and Vizzini [1] observed damage initiated at the fork point spreading to the core and solid laminate on the tapered sandwich containing foam core and 3 layers of unidirectional carbon faces loaded in tension or compression. They reported higher failure load for tapering angle $30^{\circ}$ in compare to $45^{\circ}$. Paris, et al. [2] made tensile tests of sandwich beams with $20^{\circ}$ ramp angle, aramid core and carbon faces. Strain gauges placed on faces showed that straight facesheet is much more loaded than facesheet with tapering, whereas on the solid laminate part strains were very similar. They tested different configurations where tip of the core was covered with a fiberglass cloth or filled with noodle or potted or replaced with foam denser than the original honeycomb core, but all these modifications led to lower failure load with failure initiated in the first $90^{\circ}$ ply. Change of its orientation might increase failure load. Effect of the core tip radius was tested on the tool radius $16 \mathrm{~mm}$ and $9.7 \mathrm{~mm}$ giving 30\% lower failure load for the latter.

Analytical approaches assume that the core carries out out-of-plane normal and shear stresses, facesheets carries out bending moments, normal force and in-plane shear force. These classical sandwich assumptions do not apply for the tapered sandwich which leads to more complex solution where axial forces in the facesheets are coupled with shear stress in the core. That leads to the set of differential equations solved by the finite difference method. Provided theories were usually proved by the finite element method.

For the pure bending Kassapoglou [3] computed that normal stress and shear stress in the core nonlinearly grow along ramped face from 0 to their maximum in the fork point. When varying the ramp angle, stress (especially normal stress) increase rapidly after exceeding angle $50^{\circ}$. Moment to cause failure (as well as transverse shear) increases rapidly when the ramp angle is lower than $30^{\circ}$ and also the thicker core seems to have flavor influence.

Vel, et al. [4] found optimal tapering angle for the minimum deflection caused by different contribution of the flexural and shear deflection. Peled and Frostig [5, 6], and Thomsen and Vinson [7] made stress and strain analysis based on slightly different assumptions. They found strong local bending in the faces, normal stresses and shear stresses concentrated at points where the tapering angle changes.

Among numerical approaches Yoshida, et al. [8] investigated energy release rate of a crack in butt joints. They recommend using tapering angle between $10^{\circ}$ and $15^{\circ}$ and point that optimal tapering angle depends on the panel geometry. Hirose, et al. [9] revealed (using fracture mechanics) that a small resin filler in the root of tapering strongly decreases energy release rate of crack starting there, which suppress delamination.

There can be found a lot of studies about ply drops in a solid laminate. For example review by He [10] points that internal ply drop-offs, in compare to external, are roughly twice as strong under tension, bending and torsion. Much less work is for ply drops on a sandwich core. Thomsen et al.[11, 12, 13] investigated influence of the externally tapered CFRP laminate on the constant thickness honeycomb core modeled as an elastic foundation with two parameters (normal and shear deformation) assuming that elastic wavelength is much larger than the core cell size. That gives results different from the case where the core is omitted. Ply drop caused local bending of the face, normal and shear stress in the adhesive and out-of-plane shear in the core. Stresses were higher 
if the laminate bending stiffness was smaller in compare to the core stiffness (leading to shorter elastic wavelength). Stresses are also higher if the stiffness of dropped plies is higher. Finally, they proposed failure criteria based on the stress level in "characteristic" distance from the ply drop point.

Wagschal and Venkataraman [14] investigated sandwich beam with tapered ending, constant facesheets and functionally graded core modelled with isotropic materials for the core and facesheets. They compared gradual increase of the core modulus in the tapered area from $10 \%$ of face modulus to full face modulus. They suggest that to improve the part in this way, increase of the strength of the core must be more than $10 \%$ of the modulus increase. Optimum choice might be to increase out-of-plane and shear modulus and decrease in-plane modulus. Stromsoe and Venkataraman [15] simulated densification of a honeycomb by sequential rolling along the edge before machining the tapering. They proposed convenient combination of roller diameters and depth of each rolling. Consequently Christensen, et al. [16] produced it and measured that specimens with functionally graded core had $14 \%$ better average in-plane strength in compare to non-densified ones loaded by tension.

\section{METHOD}

It was considered to build $2 \mathrm{~d}$ model in Abaqus with default geometry and layup given in the Fig. 1 . At the fork point more configurations were tested (Fig. 2): a) simple fork where 1 shell representing the left laminate area is simply forked to two shells in the tapered area, b) model was modified to include radius RS at the fork point, where small step $\mathrm{h}_{\mathrm{s}}$ was used to avoid mesh distortion in the touch point of the radius RS and bottom shell, c) filler plies were added to the left laminate part to separate shell elements continuing from the top and bottom facesheet.

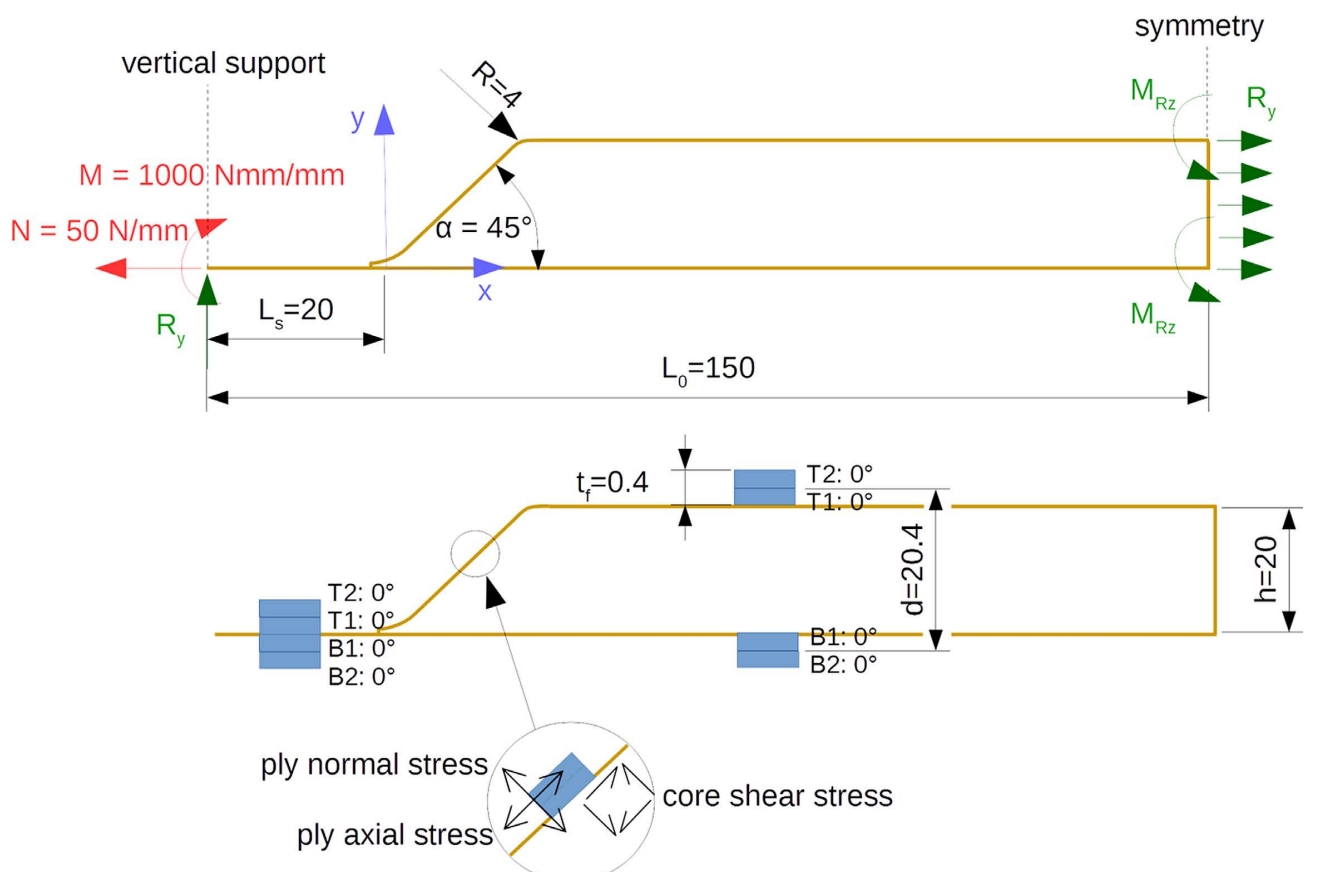

Fig. 1. Default model geometry with loads (red) and layup [own study]. 
Generic material properties were used: isotropic core elastic modulus E =1000 MPa, Poisson's number $\mu=0,3$; facesheets were modelled as shells with ply properties $\mathrm{E}_{11}=\mathrm{E}_{22}=70 \mathrm{GPa}$, shear modulus $\mathrm{G}_{12}=\mathrm{G}_{13}=\mathrm{G}_{23}=4 \mathrm{GPa}, \mu_{12}=0.1$ and with ply thickness $0.2 \mathrm{~mm}$. By default only 2 plies oriented in $0^{\circ}$ were used for each facesheet to enable clear view on axial stresses as well as local bending.

Mesh was built with quadratic volume elements for the core (C3D20R and C3D15) and conventional shell elements (S8R) for faces connect to the core. Model is only 1 element thick $(0.5 \mathrm{~mm})$ in z direction with boundary conditions in xy plane leading to plane strain. This configuration allows defining composite properties to the face shells. It was considered enough to use $0.5 \mathrm{~mm}$ mesh size except area near the fork point up to $\mathrm{x}=12 \mathrm{~mm}$ where the mesh was finer $(0,1 \mathrm{~mm})$. Model in the Fig. 2 c) was used to evaluate influence of the filler plies which are terminated right at the fork point. Filler plies were applied to the solid elements (depicted in red) between shell faces. There is 1 element in height $\mathrm{h}_{\mathrm{f}}$ with element length $0.2 \mathrm{~mm}$ along $\mathrm{x}$ direction. For defining laminate properties modulus $\mathrm{E}_{33}=10 \mathrm{GP}$ and Poisson's numbers $\mu_{23}=\mu_{13}=0.2$ were chosen.

Boundary conditions were set to get close to cross section of the sandwich panel. Symmetry boundary condition is applied to the right end. Left end is loaded and at the same time it is supported in vertical direction which simulates transversal stiffener or bulkhead. Front and back side is restrained in $\mathrm{z}$ direction to ensure plane strain (wide panel).

Two separate load cases were modelled: tension load case which gives approximation of uni-axially loaded fuselage or wing panel; bending load case giving approximation of a panel loaded by normal pressure which cause given bending moment at the sandwich ending. Modelled beam was loaded by tension $50 \mathrm{~N} / \mathrm{mm}$ which causes approximate stress $100 \mathrm{MPa}$ (strain $0.14 \%$ ) in the bottom face assuming it carries the whole load. In bending load case pure bending moment $1000 \mathrm{Nmm} / \mathrm{mm}$ was applied to cause again approximately $100 \mathrm{MPa}$ in the faces on the core high $\mathrm{h}=20 \mathrm{~mm}$. Bending load cause very large stresses in the fork point especially for non-reinforced sandwich ending, thus stress values should be taken rather for comparison.

a)

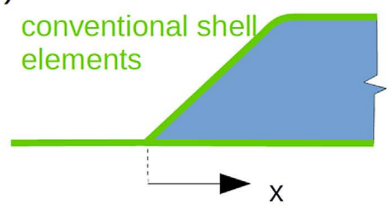

d)

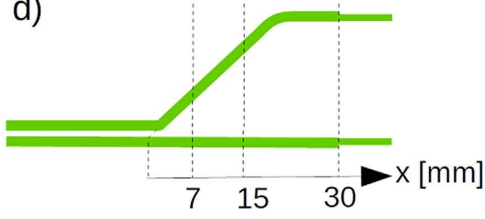

b)

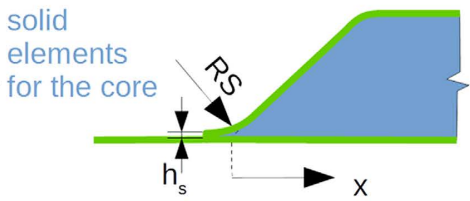

e)

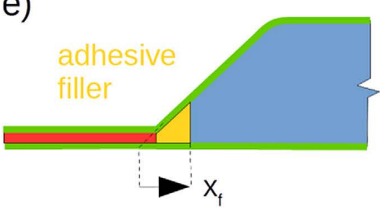

c) solid

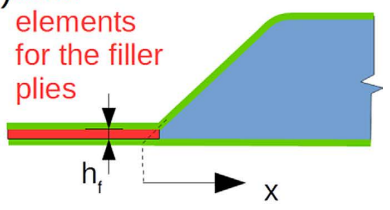

Fig. 2. Variation of the model: a) simple fork, b) fork with radius RS, c) solid laminate with filler plies, d) ply drop positions, e) adhesive filler [own study]. 


\section{RESULTS}

\section{a. Fixed parameters}

For the overall view default model was used to plot figure 3-8 for bending moment load case and tension load case. Bending moment in opposite direction and compression were not plotted because they give the same results with opposite sign to depicted graphs. Configuration c) "solid laminate with filler plies" were used around the fork point with $h_{f}=0,8 \mathrm{~mm}$ built by 4 plies in $0^{\circ}$ orientation. This was used because of different results near the fork point for models a) and c) with filler ply high $h_{f}$ approaching to 0 . Model c) uses separate shell elements for the continuation of top and bottom plies which is closer to reality.

Where the core thickness is constant, simple analytical approach yields

$$
\sigma=\frac{M}{d t_{f}}=\frac{1000}{20.4 \cdot 0.4}=122.5 \mathrm{MPa}
$$

expecting that the whole moment load $\mathrm{M}$ is taken by facesheets with thickness $\mathrm{t}_{\mathrm{f}}$ on distance $\mathrm{d}$ of their centers.

For the tension load $\mathrm{N}$

$$
\sigma=\frac{N}{t_{f}}=\frac{50}{0.4}=125 \mathrm{MPa}
$$

expecting that whole load is transferred by the bottom facesheet.

At the right side of Fig. 3 and 4 with axial stresses in farther distance from tapering $(\mathrm{x}>20 \mathrm{~mm})$ axial stresses stabilize at $109 \mathrm{MPa}$ in both facesheets for bending load case resp. $97 \mathrm{MPa}$ in the bottom and -7.5 $\mathrm{MPa}$ in the top facesheet for tension load case, due to moment equilibrium and non-zero stiffness of the core in $\mathrm{x}$-direction. Change of the force in the facesheets in the tapered area $(\mathrm{x}=0-20 \mathrm{~mm})$ reflects a change in the distance $\mathrm{d}$ between facesheets. Rough approximation by the simple formula for a beam bending leads in the fork point to $2083 \mathrm{MPa}$ (no reinforcement is applied). However, observed stresses in the fork point do not fit this estimate. In the transition between constant thickness sandwich and tapering at the top $(\mathrm{x} \sim 20 \mathrm{~mm})$ and especially in the fork point $(\mathrm{x} \sim 0 \mathrm{~mm}$ ) local bending increase stresses which is visible in splitting lines of the plies B1 and $\mathrm{B} 2$ resp. $\mathrm{T} 1$ and $\mathrm{T} 2$ of each facesheet.

As visible in figure 5 and 6 normal stresses on the core are basically 0 except areas with local bending.

Shear stresses on the core (fig. 7 and 8) converge to 0 in the constant thickness area farther from tapering $(\mathrm{x}>20 \mathrm{~mm})$. $\mathrm{X}$ position where shear stresses remain at constant value is common for the top side and bottom side. Similar behavior is for axial stresses in the facesheets. Shear stress has points with noticeable tangent change at the beginning $(x=18.5 \mathrm{~mm})$ and the end $(\mathrm{x}=21.5 \mathrm{~mm})$ of the radius $\mathrm{R}$. 


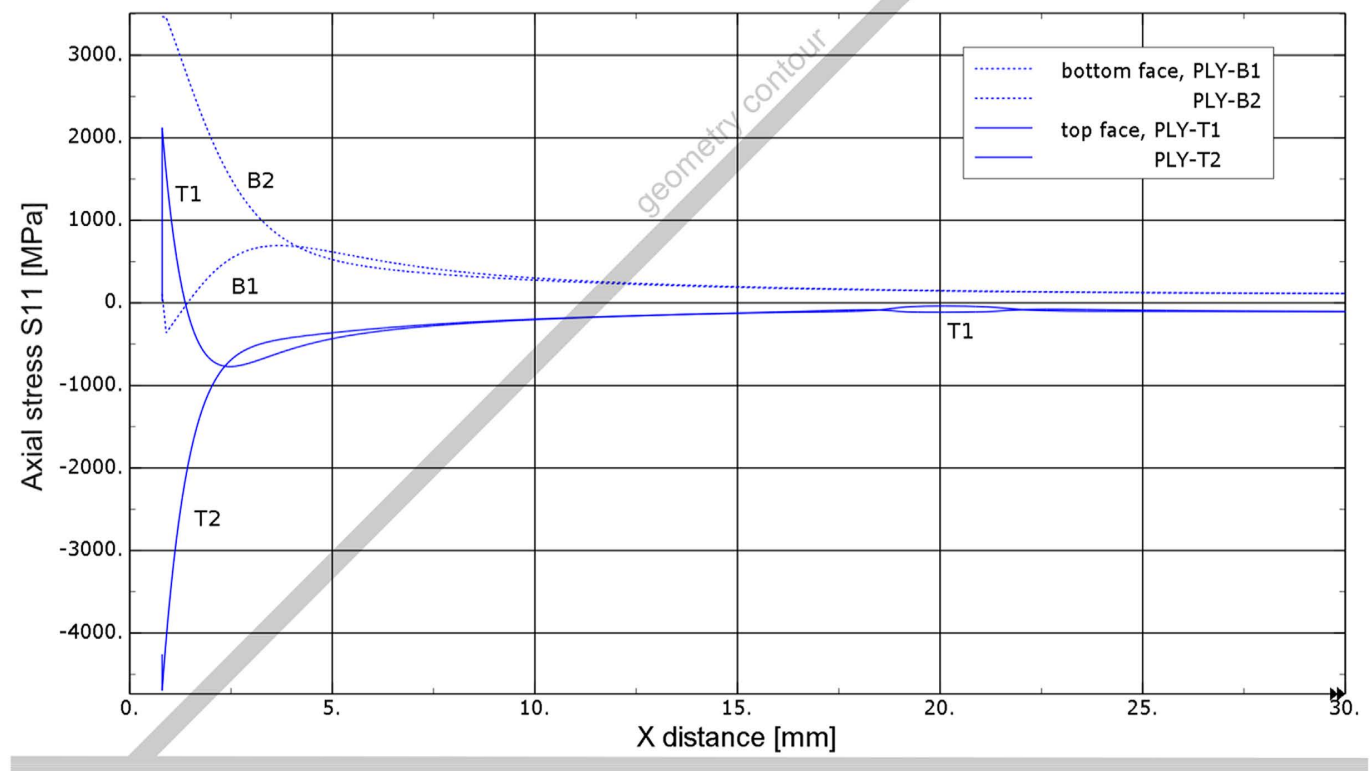

Fig. 3. Bending moment load case, stresses in the bottom and top facesheets [own study].

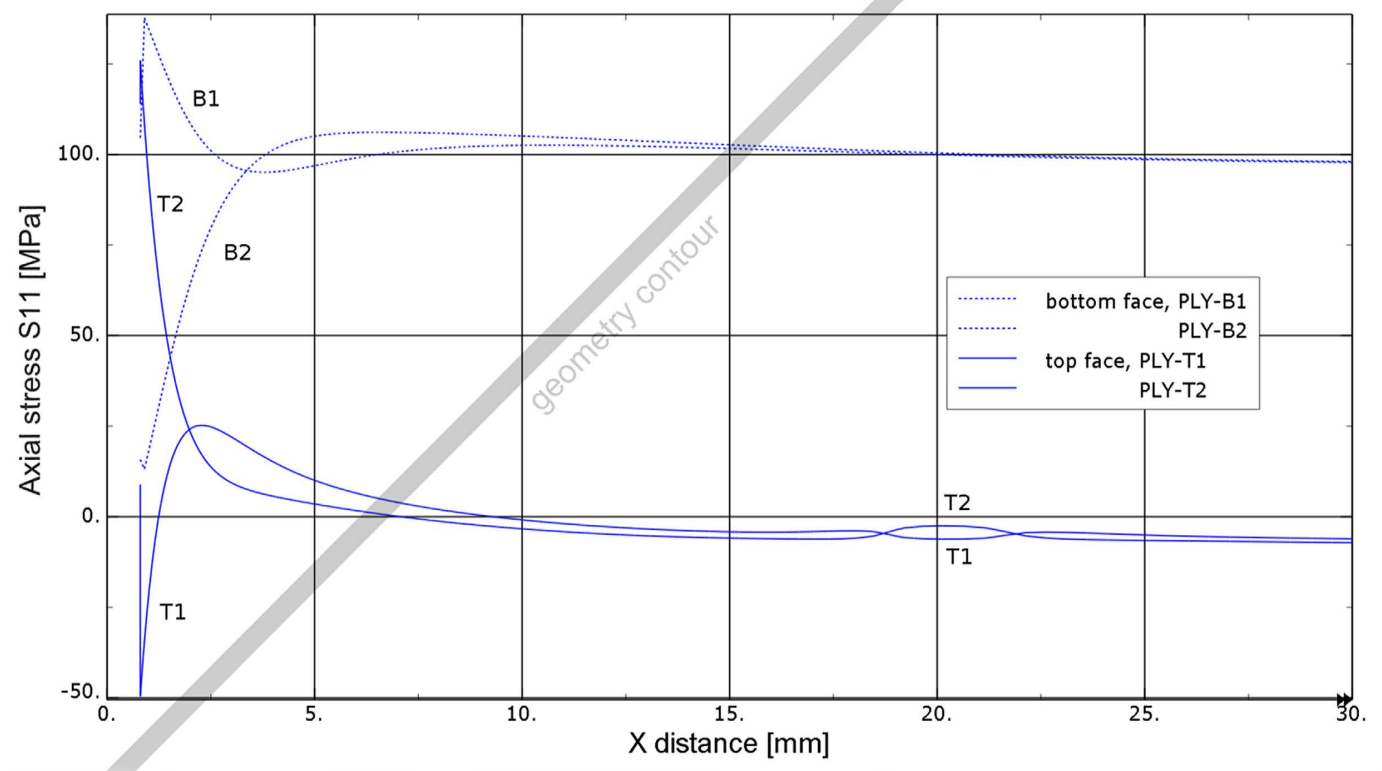

Fig. 4. Tension load case, stresses in the bottom and top facesheets [own study]. 


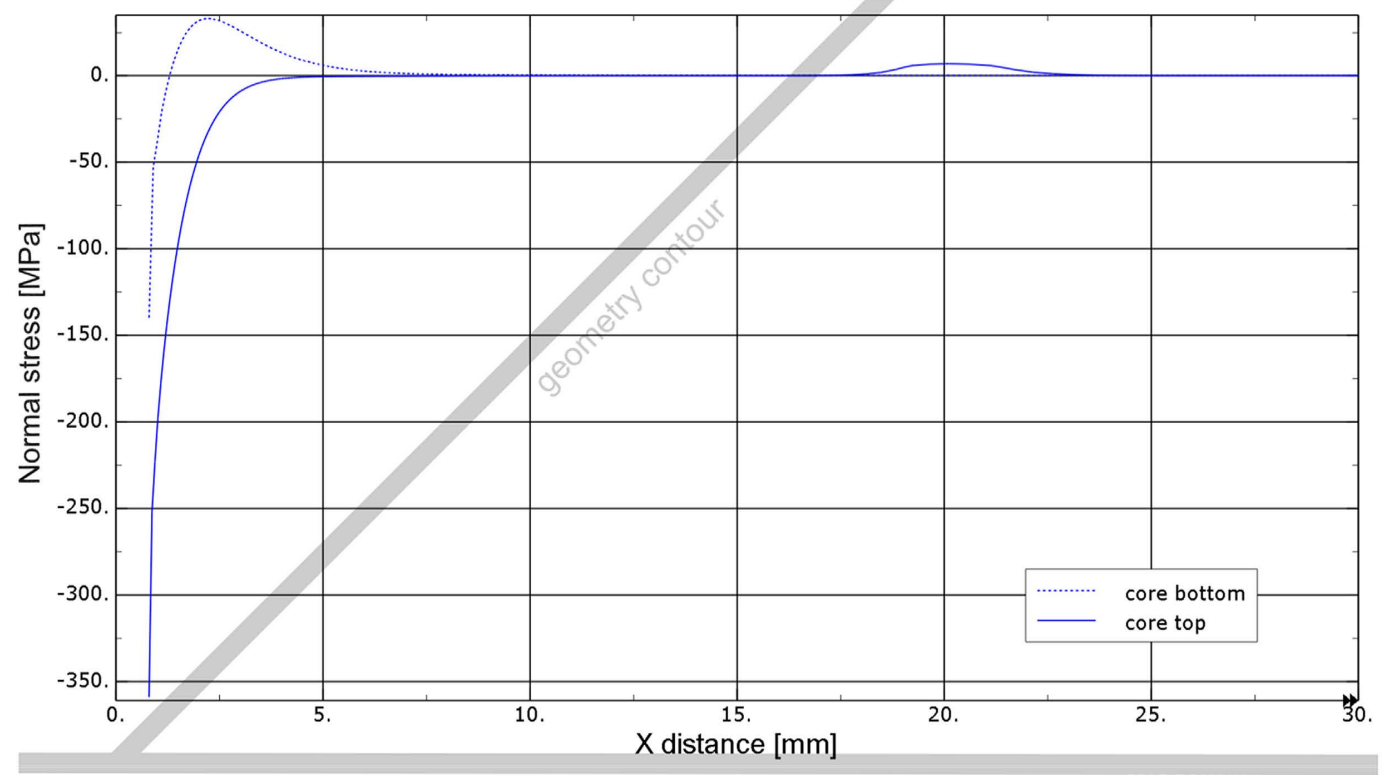

Fig. 5. Bending moment load case, normal stresses in the core bottom and top [own study].

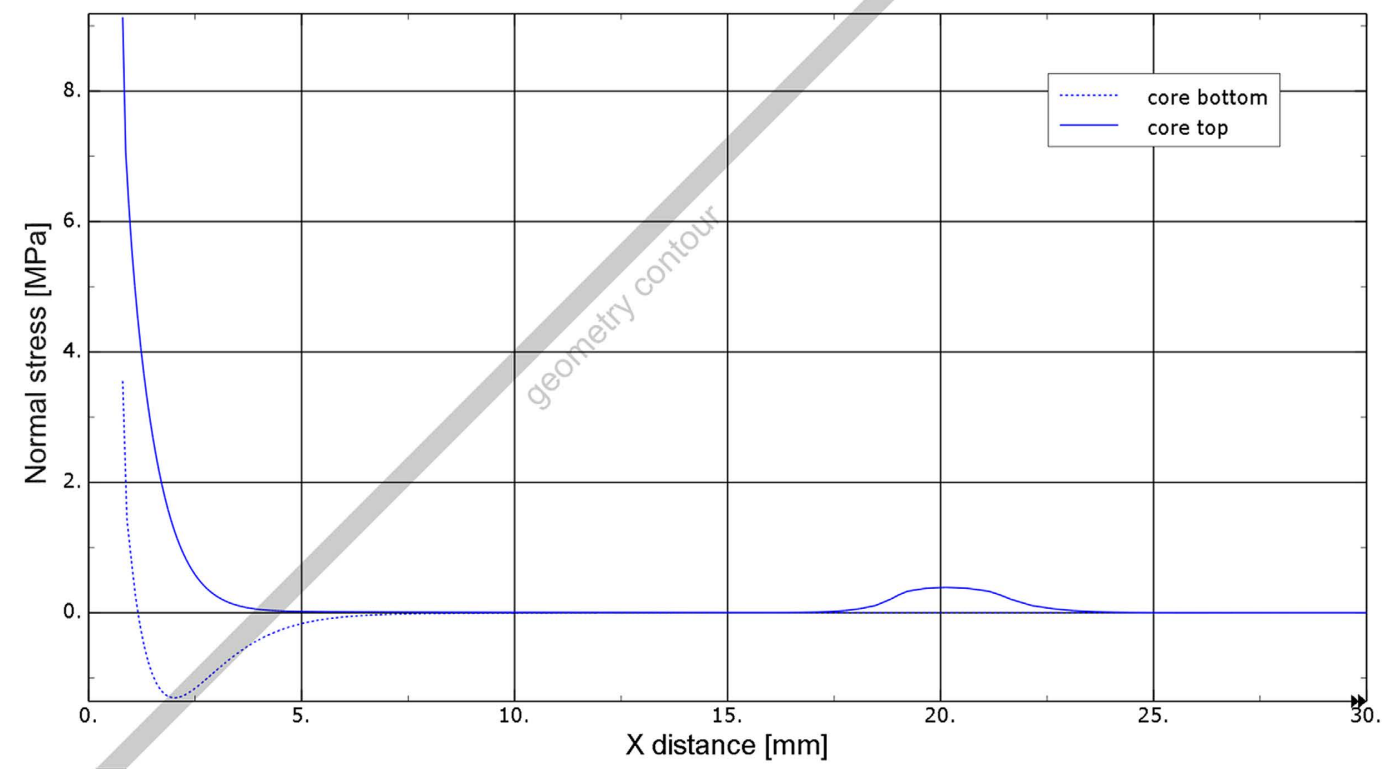

Fig. 6. Tension load case, normal stresses in the core bottom and top [own study]. 


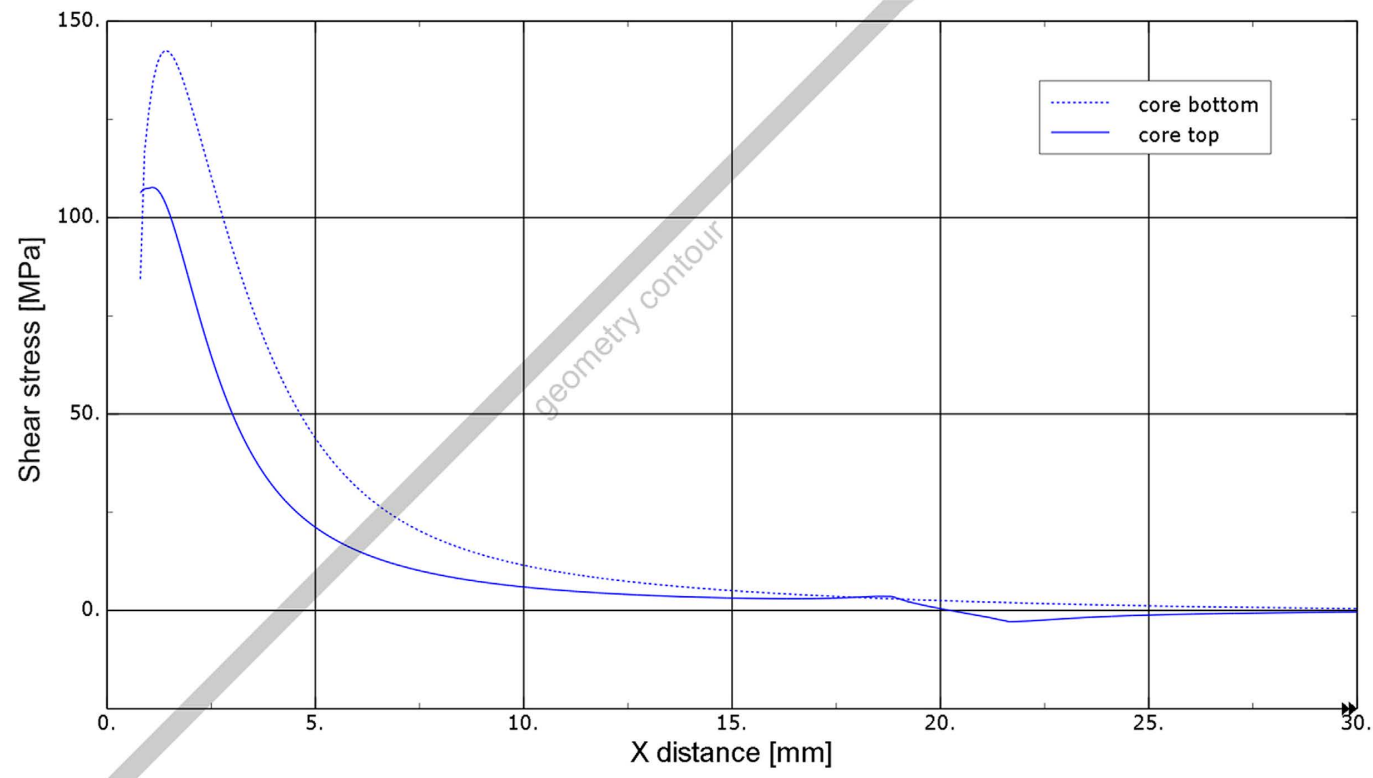

Fig. 7. Bending moment load case, shear stresses in the core bottom and top [own study].

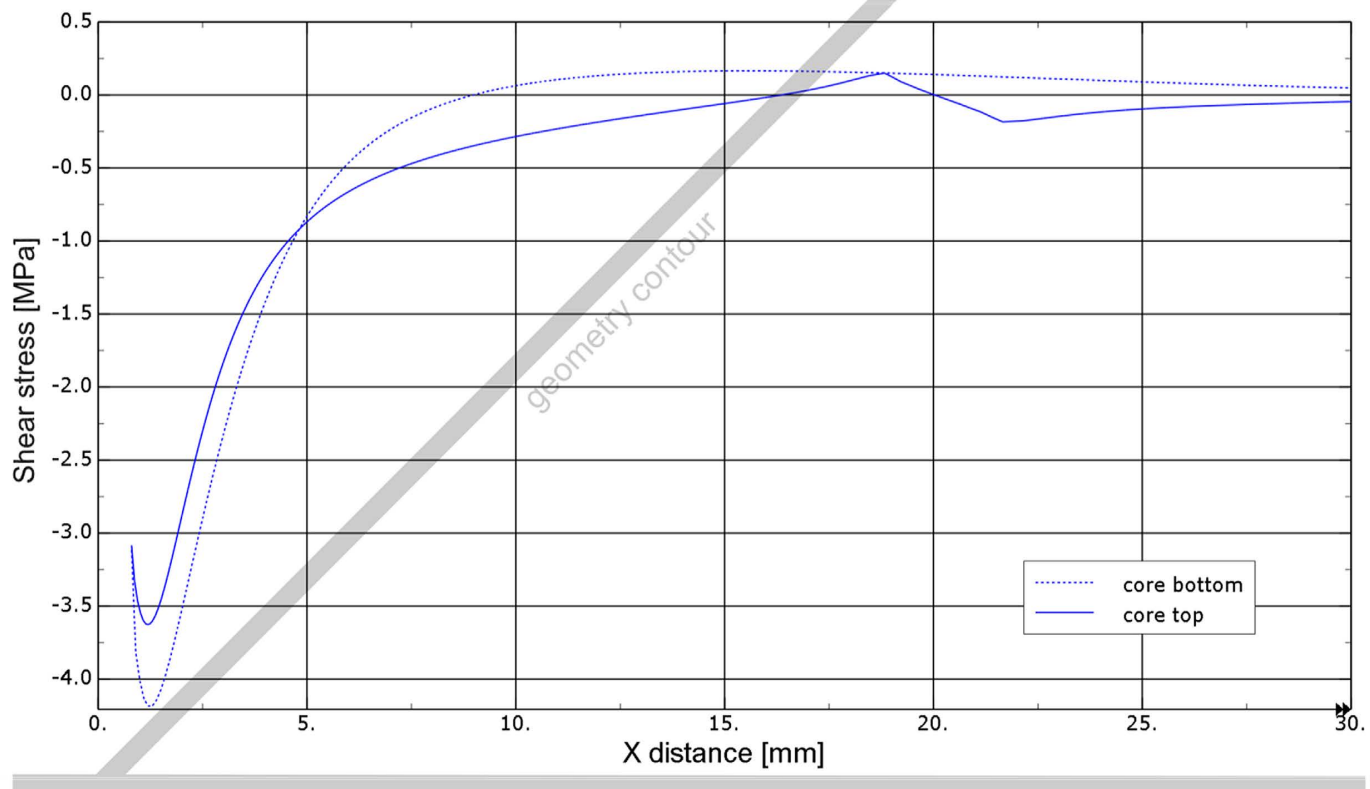

Fig. 8. Tension load case, shear stresses in the core bottom and top [own study]. 


\section{b. Variation of parameters}

Python scripts were used to automatically plot stresses along the path in the face-core boundary, which enabled to plot stresses on the core border or in the facesheet shells rapidly. Attention was paid to these because the boundary where materials change was considered as critical with view to the literature review. Loads in facesheets are represented by axial stress S11 in the middle of each ply. Normal stress and shear stress were plotted to get a view into the core-face boundary. Graphs were than visually compared in the common plot for more values of the observed parameter. This approach led to big amount of graphs from which only a few are presented below.

Model gave stable results, however stress singularities were observed for some points especially in bottom shear and normal stresses at drop points of added plies and end points of the resin filler.

\section{i. Top radius $\mathbf{R}$}

Radius on the top face was varied during pure bending load case. Basic parameters were core high $\mathrm{h}=20 \mathrm{~mm}$ and layup with 2 plies oriented in $0^{\circ}$ which enables good visualization of the local bending. Change of the tapering angle from $45^{\circ}$ to $20^{\circ}$ shifts end of the tapering from $\mathrm{x}=20 \mathrm{~mm}$ to $\mathrm{x}=55 \mathrm{~mm}$.

Higher axial stresses (fig. 9) are in the outer plies T2. Inner plies T1 (adjacent to the core) are compressed by the local bending. Approximately at the start and the end point of the radius local bending changes sign and disappears after several mm. Normal core stress (fig. 10) has extreme at the middle of the radius whereas core shear stress (fig. 11) has extremes at the start and end point of the radius. Higher values for the tapering angle $45^{\circ}$ (solid line) are due to steeper increase of

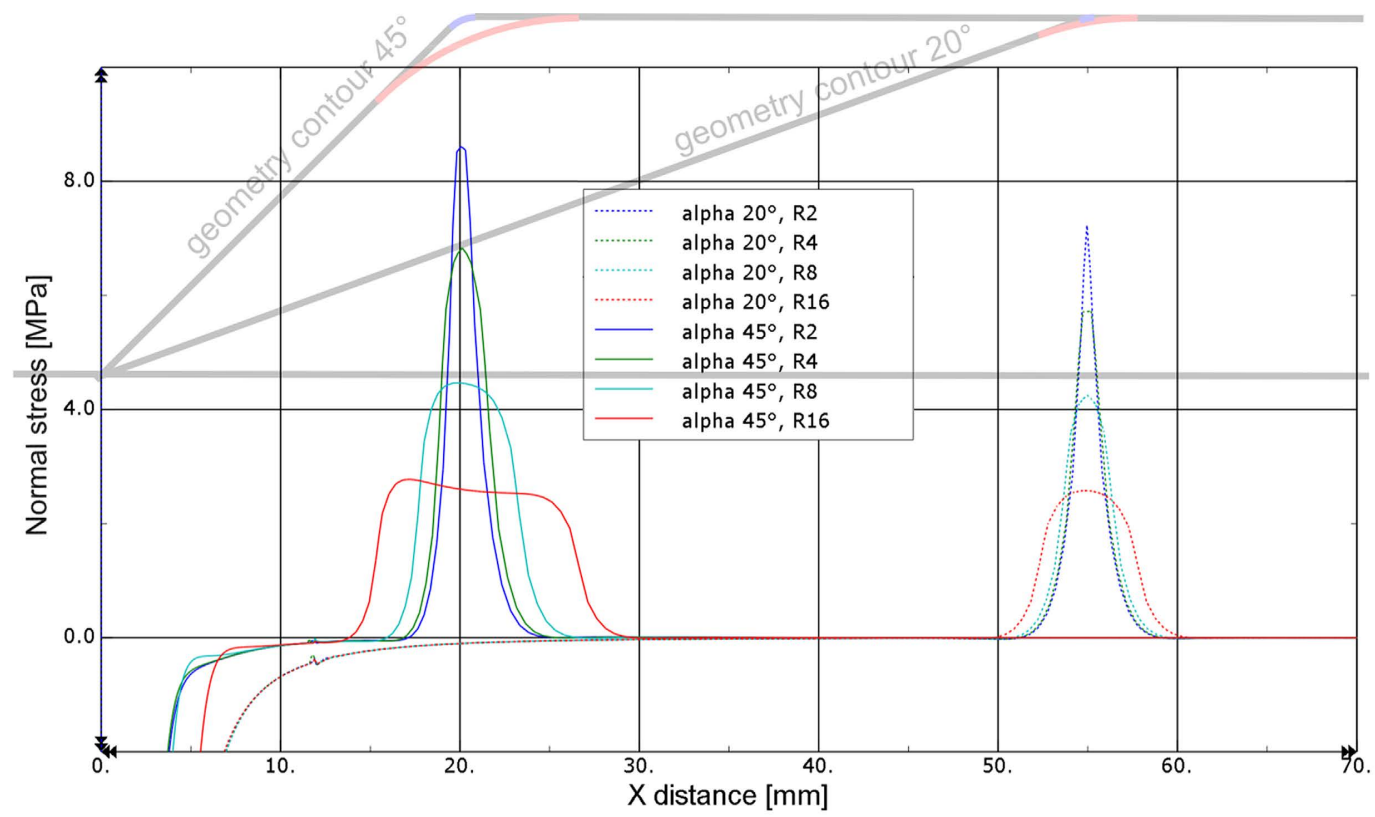

Fig. 9. Axial stresses in the plies with radius $\mathrm{R} 2 \mathrm{~mm}$ and $16 \mathrm{~mm}$ (red) for $\alpha=45^{\circ}$ and $20^{\circ}$ (dashed lines) [own study]. 


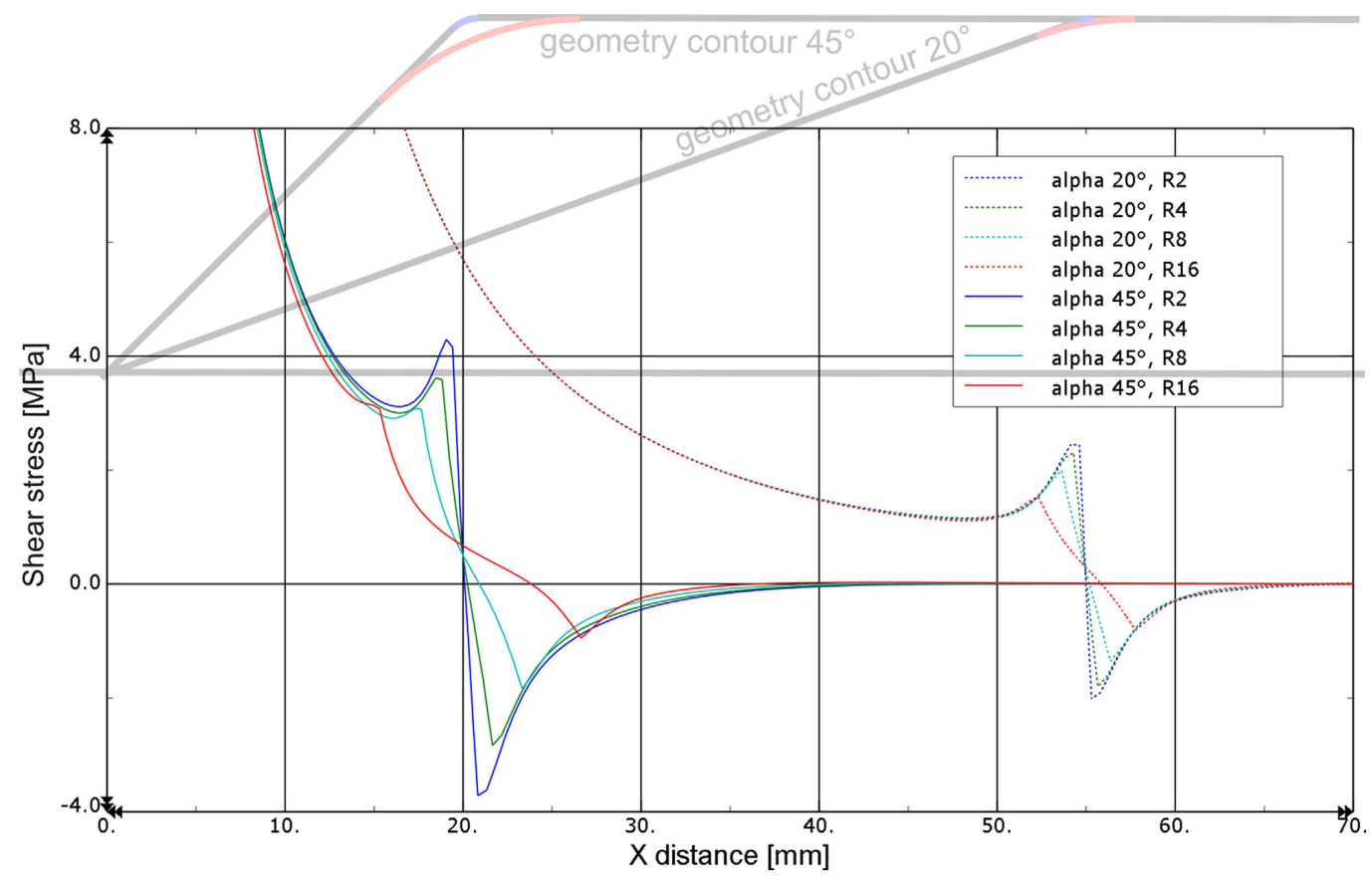

Fig. 10. Normal stresses in the core for $\alpha=45^{\circ}$ and $20^{\circ}$ (dashed lines) [own study].

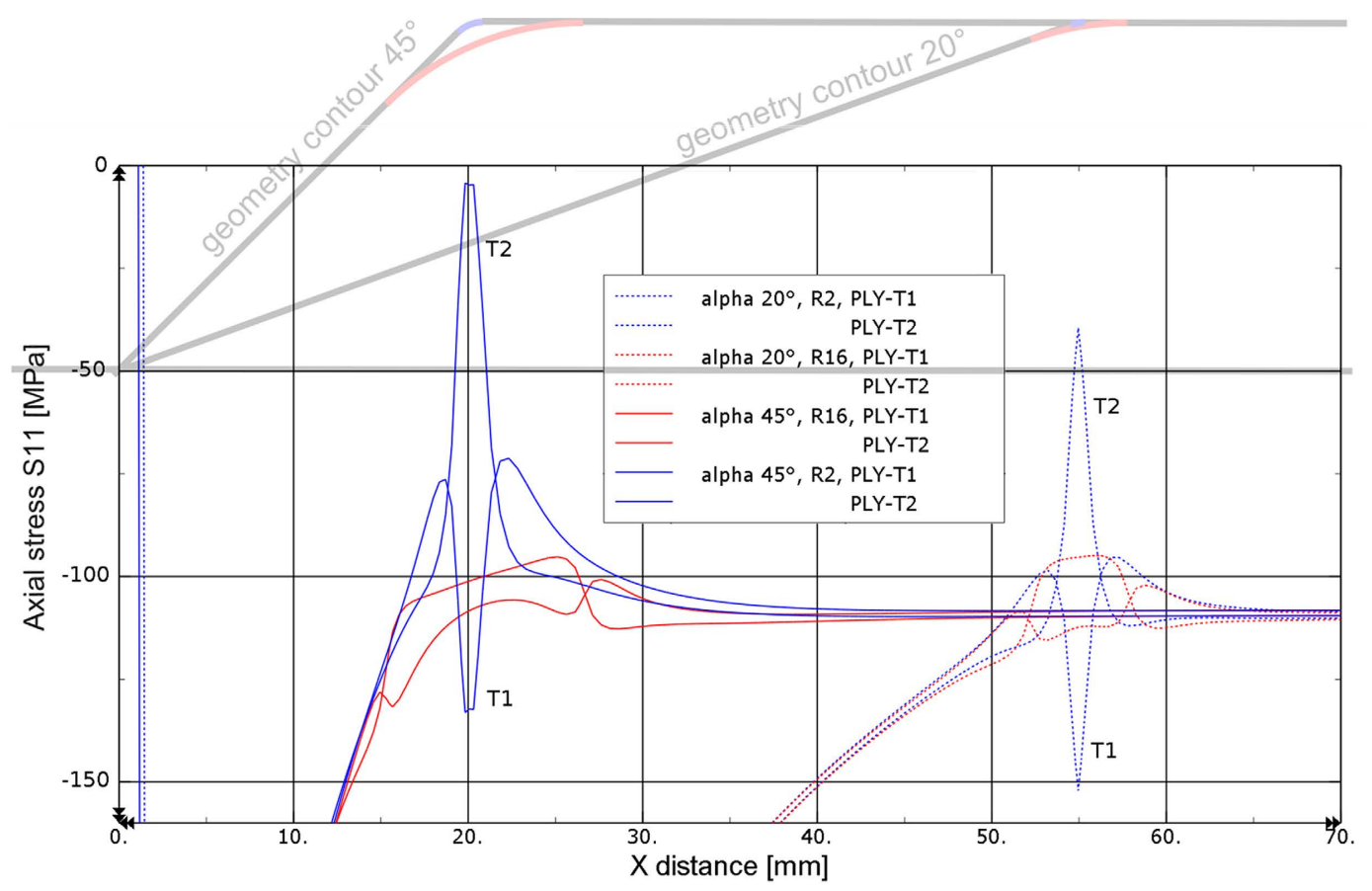

Fig. 11. Shear stresses in the core for $\alpha=45^{\circ}$ and $20^{\circ}$ (dashed lines) [own study]. 
the shear stress in the core toward the fork point. As a measure how strong the radius influence is normal core stresses were chosen and graphed in figure 12 for different tapering angles and core high. Influence of the tapering angle is low and it is not clear if it leads to stress increase or decrease. To check influence of the core high both were doubled - core high and applied bending moment to get same stress level in the constant thickness area. Higher core helps to decrease stresses, but the most important is obviously radius value which efficiently decreases stress concentrations.

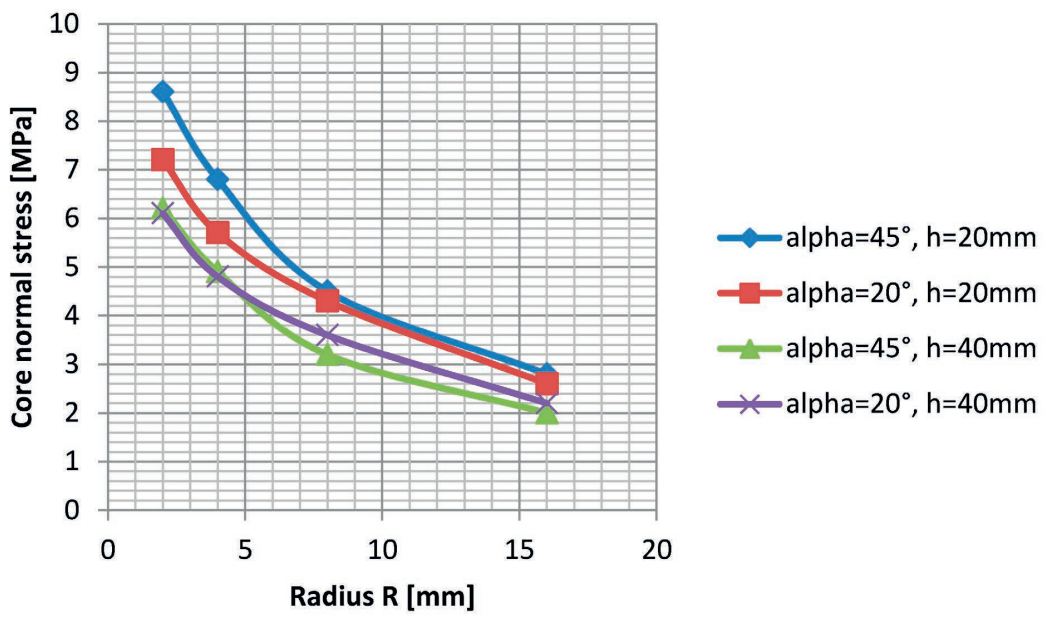

Fig. 12. Normal stresses in the core according to the radius $\mathrm{R}$ on the top of the core [own study].

\section{ii. Radius RS at the fork point}

Fork point is not possible to model as a tangential transition of the top face into the solid laminate, because there would be a singularity point. Thus the model with configuration $b$ ) in figure 2 was made where $h_{s}=0.1 \mathrm{~mm}$ denotes high of a small step which prevents the core tip to approach zero thickness under the radius. Model is not realistic directly at the step where the bottom and top shells must be connected to transmit their loads but farther along the radius stress distribution was expected to give a basic view. Testing values $\mathrm{RS}=2 \mathrm{~mm}, 4 \mathrm{~mm}, 8 \mathrm{~mm}$ and $16 \mathrm{~mm}$ did not give clear results (different tendencies in facesheet axial stresses and core stress during bending and tension load case). Local bending was still concentrated very close to the fork point and did not change much with changes within tested range. Only the shear stress peak decreased when increasing radius.

In the fork point modelling smaller and smaller radius did not approach to the solution obtained on the model without radius.

\section{iii. Tapering angle $\alpha$ and stress peaks}

Only $45^{\circ}$ and $20^{\circ}$ were compared. There was a difference between behavior of the model (a) with simple fork and model (b) with the radius RS (fig. 2). For the simple fork (a) higher angle $45^{\circ}$ gave $15 \%$ higher local bending in the top facesheets whereas in the bottom facesheet $20^{\circ}$ angle gave $30 \%$ 
higher local bending. Normal stress was for $20^{\circ}$ angle higher by roughly $80 \%$ resp. $40 \%$ on the top resp. on the bottom of the core.

In the model with radius (b) stress peaks were not influenced by the tapering angle as if even small radius $\mathrm{RS}=2 \mathrm{~mm}$ locally erases influence of the angle. Considering real manufacturing in the fork point area plies have some natural radius due to their continuity, but involving very small radius comparable to face thickness needs modeling faces in more detail than with shell elements in this study.

\section{iv. Filler plies in the solid laminate}

In practise several filler plies are used in the solid laminate to increase its height needed for countersunk bolts. It also increase effective height at the fork point which was expected to lower the stresses.

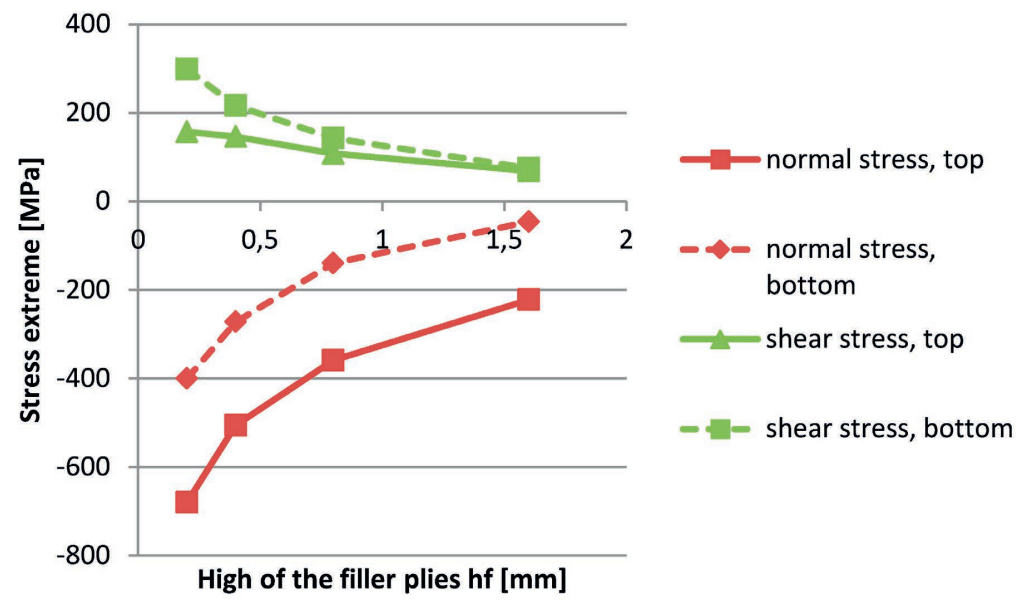

Fig. 13. Bending moment load case, extreme axial stresses in the facesheet plies [own study].

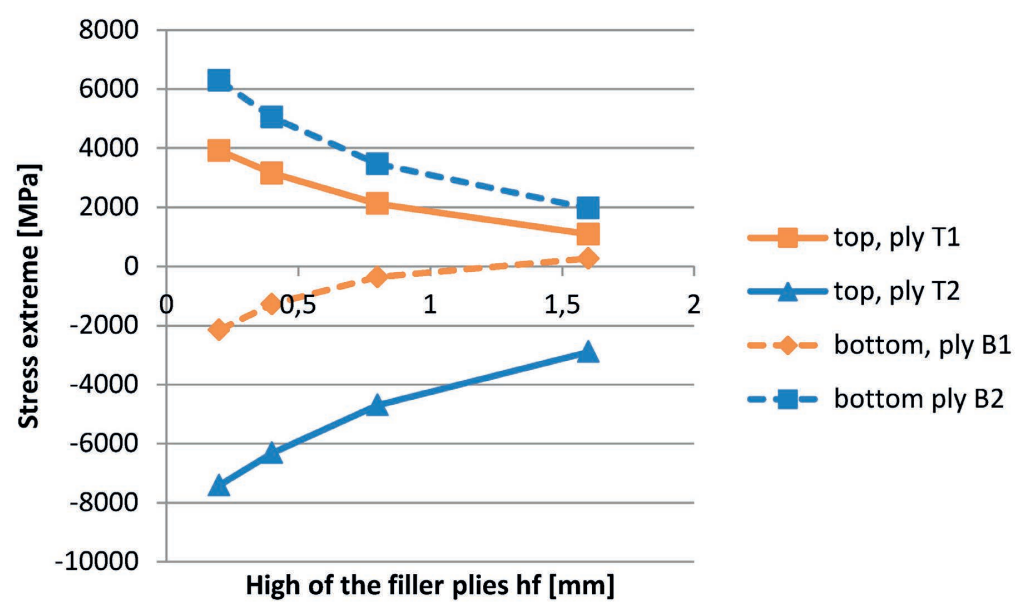

Fig. 14. Bending moment load case, extreme stresses on the bottom and top core surface [own study]. 
It was found that model with filler elements does not behave as model with simple fork, giving qualitatively different stress distribution near the fork point, but existence of extreme stress peaks and local bending remained. Extreme values are for the bending load case in figure 13 where decrease is visible in local bending and figure 14 where is stresses on the core surface is visible. That can be explained by decreasing load in the facesheets due to bigger effective high built by filler plies.

During tension load case, where load is transmitted mainly by the bottom facesheet, increasing of the solid laminate thickness by filler plies decrease only extremes in shear and normal stress along the bottom core surface. Nevertheless, these stress peaks (normal and shear) are relatively low (6 $\mathrm{MPa}$ and 4.7 MPa for normal resp. shear stress both for $\mathrm{h}_{\mathrm{f}}=0.2 \mathrm{~mm}$ ). So, from the tensional load case point of view increasing thickness of the solid laminate does not seem to be necessary.

\section{v. Reinforcing plies}

Adding plies is a way of reinforcing tapered end reflecting distance between faces. First, only one added ply on the each face was modeled for dropping at three different positions: at $\mathrm{x}=7 \mathrm{~mm}$, $15 \mathrm{~mm}$, and $30 \mathrm{~mm}$, where in the last one faces are yet horizontal (fig. 2d). Than 1, 2, and 3 plies were added to see the effect in the fork point.

Ply drop crates certain stress concentration. For the bending moment: if compared stress level with non-reinforced layup, concentrations creates axial increase by roughly $50 \mathrm{MPa}$ wherever is the ply dropped. Shear stress change is very small. Normal stress peak also small (about $2 \mathrm{MPa}$ ), slightly higher in the first ply drop position where interacts with the fork point concentrator.

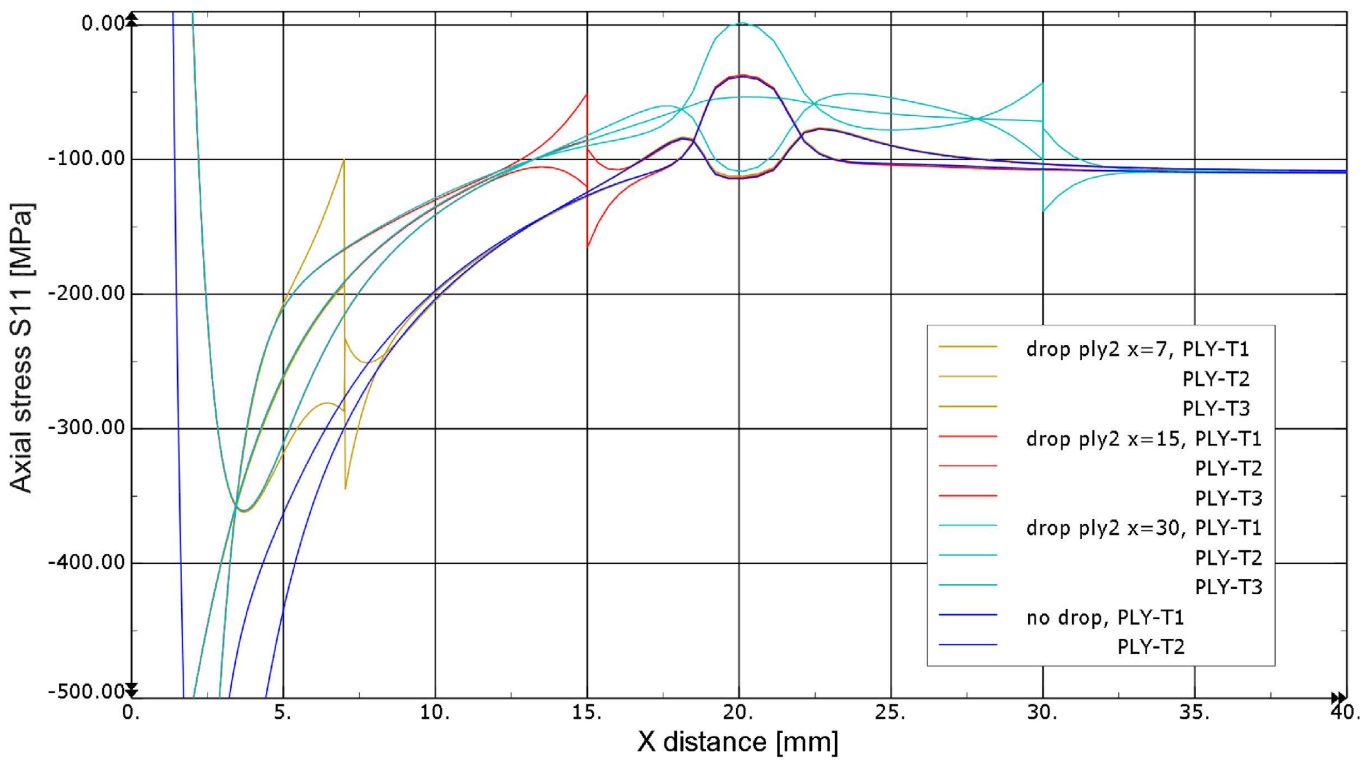

Figure 15. Bending load case, axial stresses in the top facesheet plies. Peaks show result of the different ply drop position [own study]. 
Local extreme of the axial stress in the radius area $(\mathrm{x} \sim 20 \mathrm{~mm})$ is not improved much, when added ply covers radius area and is dropped further. Normal stress used as a measure of the stress concentration dropped from $6.8 \mathrm{MPa}$ to $5.9 \mathrm{MPa}$ when added 3rd ply, but when changed radius from $4 \mathrm{~mm}$ to $8 \mathrm{~mm}$ normal stress drops from 6.8 $\mathrm{MPa}$ to $4.5 \mathrm{MPa}$. So adding plies is not as effective as increasing radius.

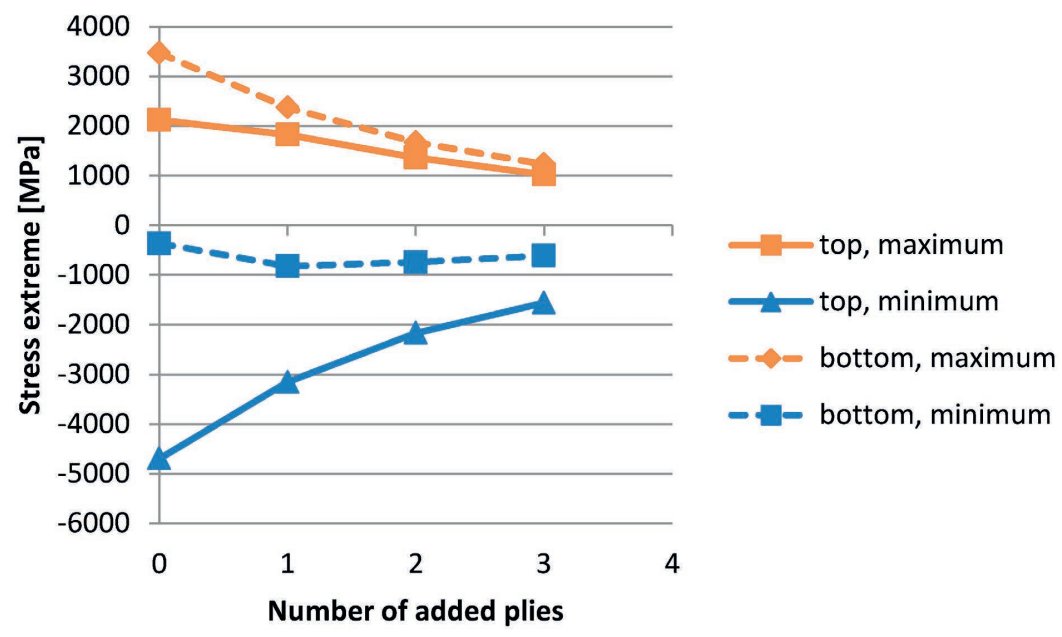

Fig. 16. Bending moment, extreme axial stresses in the facesheet plies near the fork point [own study].

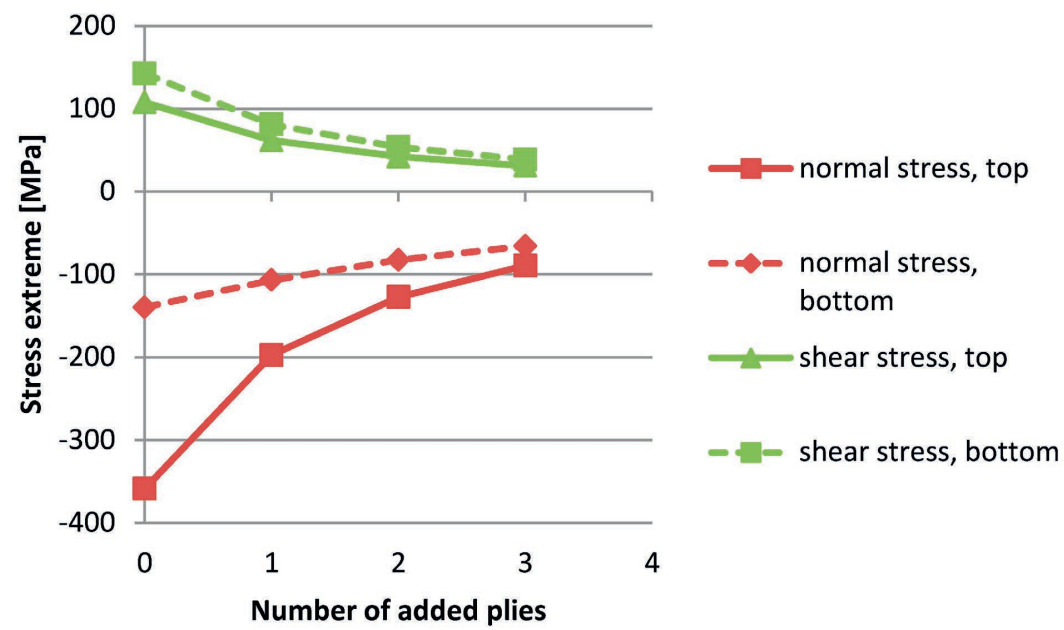

Fig. 17. Bending moment, extreme stresses on the bottom and top core surface near the fork point [own study].

Model with continuous shell element properties for facesheets gives only orientational values of stress concentrations in the ply drop positions. In the axial stresses peak was about $50 \mathrm{MPa}$ in addition to nominal stress, which is quite a lot if we consider that design load out of tapering area was about $100 \mathrm{MPa}$. Peak disappeared in the distance of rougly $3 \mathrm{~mm}$ from the ply drop point. 
During bending moment normal and shear stress peaks were small in compare to peaks caused by transition from tapering to constant thickness sandwich.

Shape of the stress peaks (e.g. facesheet stress figure 15 at $\mathrm{x}=7 \mathrm{~mm}, 15 \mathrm{~mm}$ and $30 \mathrm{~mm}$ ) cause that ply drop is convenient just at the beginning of the radius $\mathrm{R}$ (trasition from tapering to radius) or just at the end of the radius (transition from radius to horizon) where axial stresses and normal stresses subtract. Only in the case of ply drop just after radius shear stress slightly increases there.

It is possible to decrease fork point stress by adding more plies. Figures 16 and 17 show influence of reinforcing on the stress extremes during bending load case. Axial stresses in the facesheets as well as normal and shear stresses on the core surface decrease. That can be explained by increasing bending stiffness which eliminates stresses due to local bending which is still present. For tension load case tendencies were similar.

\section{vi. Adhesive filler}

Adhesive or resin filler with elastic modulus E $=3000 \mathrm{MPa}$ (3 times more than core) and Poisson's number 0.3 was added to the last configuration, i.e. filler plies with high $0.8 \mathrm{~mm}$ and 3 added plies dropped at positions 1, 2, and 3 as mentioned before. Resin filler continues from the point where filler plies ended $(\mathrm{x}=0.8 \mathrm{~mm})$ to the position $\mathrm{x}=2.8 \mathrm{~mm}$ or $\mathrm{x}=5$ or $\mathrm{x}=10 \mathrm{~mm}$ (fig. $2 \mathrm{e}$ ).

For bending load case von Mises core stress extreme in the filler is 2,4 times higher than in the core without filler (227 MPa instead of $93 \mathrm{MPa}$ ). That is caused by 3 times higher elastic modulus of the filler, thus carrying more load. When the filler is longer, stress extreme do not drop significantly but stress step between the filler and the core is less dramatic.

Introducing filler makes certain dicrease of the local bending of the facesheets at the fork point so the facesheet stresses are lower, but at the same time shear and normal stresses increase due to more load transfer through the filler, which is stiffer then the replaced core.

\section{SUMMARY}

Tapered sandwich ending was simulated on the " $2 \mathrm{D}$ " model with isotropic core and conventional shell elements for composite facesheets. Default model gave basic stress distribution similar to the previous studies. Axial stresses in the facesheets point to local bending at the fork point in both facesheets and smaller one at transition from tapered to constant thickness. Normal stress on the core surface is 0 except local bending areas. Shear stress on the core surface is 0 in the constant thickness area, but it increases in the tapering towards the fork point. Especially shear stress area influenced by the transition from constant thickness to a tapered sandwich is wider than geometrical radius applied there.

Approximately $6 \mathrm{~mm}$ distance between ply drops is needed to avoid their interaction according to model with conventional shell elements for the facesheets, but a more detailed model can give slightly different results.

Influence of the tapering angle on the stress peaks near the fork point is not clear because model with simple fork gave better results for the $20^{\circ}$ angle, but model with radius RS seemed as even small radius erase influence of the tapering angle. 
Filler plies in the solid laminate decrease stresses caused by the bending load case. In the tension load case only bottom normal and shear stresses on the core decreased whereas others remained on approximately the same level.

Adhesive or resin filler with 3 times higher modulus than core decreased local facesheet bending but also significantly increased shear and normal stresses. Longer fillers did not give much different results from short one $(\mathrm{x}=2.8 \mathrm{~mm})$.

\section{a. Recommendations}

Stress concentration at the transition point where top facesheet narrows can be effectively decreased by using radius $\mathrm{R}$. Adding reinforcing plies there and using higher core decreases stresses much less. Ply drop situated at the beginning of the radius (tapering-radius transition) and at the end of the radius (radius-horizon transition) interact fluently.

For tension load case reinforcement is not almost needed because the whole load is carried out by bottom facesheet, thus only small ply overlap around the fork point (and short adhesive filler) seem to be enough to secure stress concentration. For bending load case situation is different because tapering extremely decrease effective high of the sandwich. Thus plies must be added along the tapering. Due to big local bending at the fork point extra plies are needed there and few millimeters long adhesive filler may help as well as filler plies increasing high of the solid laminate part.

It is important to note that failure criteria were not included in this study and stress concentration around the fork point needs to be checked with more detail modelling and respect to the manufacturing.

\section{ACKNOWLEDGMENT}

The research was made during an internship at KTH under polite supervision of prof. Malin Åkermo and in close cooperation with Saab through mentor prof. Tonny Nyman. The internship was supported by the Erasmus+ six month scholarship. Special thank is also to Mikael Petersson from Saab for practical introduction to sandwich manufacturing. Outputs were also supported by the project NETME Centre, regional R\&D centre built with the financial support from the Operational Programme Research and Development for Innovations within the project NETME Centre (New Technologies for Mechanical Engineering), Reg. No. CZ.1.05/2.1.00/01.0002.

\section{BIBLIOGRAPHY}

[1] Kuczma, S. K, Vizzini A. J., 1995, "Failure of Sandwich to Laminate Tapered composite Structures", $36^{\text {th }}$ Structures, Structural Dynamics and Materials Conference, AIAA - American Institute of Aeronautics and Astronautics, New Orleans LA, DOI: 10.2514/6.1995-1389

[2] Paris, I. L., 2009, “Characterization of Composites Sandwich Ramp Failure under Tensile Loading", 17th International Conference on Composite Material, Edinburgh

[3] Kassapoglou, C., 1996, "Stress Determination and Core Failure Analysis in Sandwich Rampdown Structures under Bending Loads", Key Engineering Materials, 120-121, pp 307-328, ISSN: 1662-9795, Doi: 10.4028/www.scientific.net/KEM.120-121.307 
[4] Vel, S. S, Caccese, V, Zhao, H., 2002, "Modeling and Analysis of Tapered Sandwich Beams", Proceedings of the American Society of Composites, Seventeenth Technical Conference, Purdue University, West Lafayette, Indiana

[5] Peled, D, Frostig, Y., 1994, "High-Order Bending of Sandwich Beams with Transversely Flexible Core and Nonparallel Skins”, Journal of Engineering Mechanics, 120(6), ISSN (print): 0733-9399, ISSN (online): 1943-7889, DOI: 10.1061/(ASCE)0733-9399(1994)120:6(1255)

[6] Frostig, Y, Peled, D, 1995, "High-order bending of piecewise uniform sandwich beams with a tapered transition zone and a transversely flexible core", Composite Structures, 31(2), pp 151-162, doi: 10.1016/0263-8223(95)00012-7

[7] Thomsen, O. T, Vinson, J. R., 2002, "Modeling of Tapered Sandwich Panels Using a High-Order Sandwich Theory Formulation”, AIAA Journal, 40(9), ISSN: 0001-1452, EISSN: 1533-385X, DOI: $10.2514 / 2.1866$

[8] Yoshida, K, Hirose, Y, Mori, Y., 2011, "A Study on Design Procedure of Foam Core Sandwich Panel Joint Based on Fracture Mechanics", 18th international conference on composite material ICCM 2011, Jeju, South Korea

[9] Hirose, Y, Nishitani, M, Ochi, W, Fukumoto, K, Kawasaki T, Hojo M., 2006, "Proposal of suppression of delamination for the foam core sandwich panel joint with filler", Adv. Composite Mater., 15(3), pp. 319-339, ISSN: 0924-3046 (Print) 1568-5519 (Online), DOI: $10.1163 / 156855106778392061$

[10] He, K, Hoa, S. V, Ganesan, R., 2000, “The study of tapered laminated composite structures: a review", Composites Science and Technology, 60(14), pp 2643-2657, ISSN 0266-3538, doi: 10.1016/S0266-3538(00)00138-X

[11] Thomsen, O. T, Rits, W, Eaton, D.C. G, Brown S., 1996, "Ply drop-off effects in CFRP/ honeycomb sandwich panels — theory", Composites Science and Technology, 56, pp. 407-422, ISSN: 0266-3538, doi: 10.1016/0266-3538(95)00145-X

[12] Thomsen, O. T, Rits, W, Eaton, D.C. G, Dupont, O, Queekers, P., 1996, "Ply drop-off effects in CFRP/honeycomb sandwich panels - experimental results", Composites Science and Technology, 56, pp. 423-437, ISSN: 0266-3538, doi:10.1016/0266-3538(96)00007-3

[13] Thomsen, O. T, Mortensen, F, Frostig, F., 2000, "Inteface failure at ply drops in CFRP/ honeycomb sandwich panels", Journal of Composite Materials, 34(2), pp. 135-157, ISSN: 00219983, eISSN: 1530793X, DOI: 10.1106/EM8V-D484-KYH4-81H9

[14] Wagschal, K. R, Venkataraman, S., 2013, "Numerical Investigation of Tapered Sandwich Closeouts with Isotropic Functionally Graded Cores", 54th AIAA/ASME/ASCE/AHS/ASC Structures, Structural Dynamics, and Materials Conference, Boston, Massachusetts, DOI: 10.2514/6.2013-1545

[15] Stromsoe, J, Venkataraman, S., 2012, "Functionally Grading Honeycomb Core Material by Inplane Crushing for Tapered Sandwich Closures", 53rd AIAA/ASME/ASCE/AHS/ASC Structures, Structural Dynamics and Materials Conference, Honolulu, Hawaii, DOI: 10.2514/6.2012-1702

[16] Christensen, A. L, Sens, B. T, James, S. P, Venkataraman, S., 2013, "Testing of Sandwich Composite Edge Closeouts with Functionally Graded Honeycomb Cores", 54th AIAA/ASME/ASCE/AHS/ASC Structures, Structural Dynamics, and Materials Conference, Boston, Massachusetts, DOI: 10.2514/6.2013-1549 


\section{BADANIE ROZKLADU NAPRĘŻEŃ W UKOSOWANYCH ZAKOŃCZENIACH STRUKTURY PRZEKŁADKOWEJ}

\section{Streszczenie}

Jednym z typowych rodzajów zakończeń struktury przekładkowej jest stożkowe (klinowe) przejście do laminatu, które w istotny sposób wpływa na zmianę rozkładu naprężeń. Na podstawie literatury stwierdzono, że powierzchnia klinowa powoduje: wzrost naprężeń ścinających w rdzeniu, sił osiowych w pokryciach, lokalne zginanie w obszarze zamknięcia laminatu, w miejscach zmiany kąta klina oraz w obszarach wygubiania warstw. Największą uwagę poświęcono zakończeniom bez dodatkowych wzmocnień. Podczas projektu realizowanego w ramach programu ERASMUS+, dotyczącego modelu dwuwymiarowego uwzględniającego zakończenie klinowe przeanalizowano wpływ kształtu struktury oraz rodzaju zastosowanego wypełniacza na rozkład naprężeń. Wykazano, że w przypadku obciążenia rozciągającego nie jest ono tak krytyczne jak obciążenie zginające. Zwiększając grubość laminatu, dodając warstwy oraz wprowadzając wypełniacz żywiczy lub klejowy w obszarze szczytu rdzenia prowadzi do redukcji naprężeń, natomiast w punkcie przejścia z powierzchni klinowej do stałej grubości rdzenia wzrost promienia jest bardziej efektywny aniżeli wzmocnienie dodatkowymi warstwami w odniesieniu do redukcji koncentracji naprężeń.

Słowa kluczowe: zakończenia struktury przekładkowej, stożkowe przejście do laminatu, klinowe przejście do laminatu, zamknięcie, MES, wypełniacz, wygubianie warstw. 